\title{
THE INFLUENCE OF THE VARIATION OF WEIGHT UPON THE JUDGMENT OF EXTENT.
}

\author{
By William Wilberforce Costin, Ph.D.
}

In the study of illusions it is sometimes found that the experiment may be reversed and the result still be an illusion. It is interesting to note that the well known illusion of Aristotle in which the deception of touch is brought out-as when a pencil is placed between the crossed index and second finger and two pencils are felt to be there instead of one-has its converse, as seen in the fact that two objects quite a distance apart when touched by the crossed fingers will produce an impression similar to that habitually produced by a single object. The fact of the converse of Aristotle's illusion led to the question of the possibility of the converse to what is known as the weight-size illusion.

In the weight-size illusion the size clearly affects the apparent weight. For instance, equal weights ( $5 \circ \mathrm{gr}$.) are compared while concealed in two boxes of different sizes. It is found, by lifting, that the weight in the larger box seems lighter than that in the smaller when they are in fact equal. The sight of the larger box leads the mind, guided by experience, to judge that it is heavier than the smaller. "But the actual weight of the larger box is so much less than the mind anticipates, and so much less than the hand is prepared to raise, that by contrast it seems much lighter than it otherwise would." 1 This illusion suggested the question as to what in some respects is, and in some respects is not, its converse, namely, what effect the variation of weight would have upon the judgment of extent.

In preparing for the experiment the following materials were employed: Rectangular blocks of rosewood were selected, cut and finished with constant dimensions in cross-section $22 \mathrm{~mm}$. $\times 30 \mathrm{~mm}$., but with lengths running from $42 \mathrm{~mm}$. to

${ }^{1}$ Stratton, Experimental Psychology, p. 98. 
$54 \mathrm{~mm}$. by steps of $1 \mathrm{~mm}$. Thirteen blocks in all constituted the series. They were loaded invisibly with small shot and paraffine until each weighed 50 grammes. In addition to these there were three blocks called standards all of the same dimensions, namely, $22 \mathrm{~mm}$. $\times 30 \mathrm{~mm}$. $\times 48 \mathrm{~mm}$. but of the following weights: $5^{\circ} \mathrm{gr} ., \mathrm{I} 5 \mathrm{gr}$, and $85 \mathrm{gr}$.

Two methods were used in the experiment. The first the method of minimal changes. The second that of right and wrong cases, with some modification.

In the use of the first method all the blocks were employed, the series alternating from $42 \mathrm{~mm}$. to $54 \mathrm{~mm}$. throughout the experiment, and the three standards likewise. The subject, blindfolded, takes a position on the opposite side of the table from the experimenter, seated with his right side to the table. With his arm lengthwise with the table he holds his hand ready to lift each block, beginning with the standard, with its ends between the thumb and the second and third fingers.

Placed between the standard and the subject, half an inch away, was the first variable of the series. At the word 'ready' the subject reached forward and took the standard between his thumb and second and third fingers and lifted it from six to eight inches high. Then putting it down he took up the variable in the same way and gave a judgment as to whether the second in comparison with the first was longer, shorter or equal, or whatever his judgment might be. In this manner the whole series was gone through, both down and up, making twentysix judgments in all for that standard. Then the $15 \mathrm{gr}$. and the $85 \mathrm{gr}$. standards were used in the same way. Seventy-eight judgments constituted one 'sitting.' This was all that was required of the subject in one day. Altogether there were seven subjects and each had five 'sittings,' a total of two thousand seven hundred and thirty judgments. Much care was taken to vary the order of series. Each subject in five sittings, was given the following variations in the standards employed: (I) I 5 gr., 50 gr., 85 gr.; (2) 85 gr., 15 gr., 50 gr.; (3) 50 gr., I 5 gr., 85 gr.; (4) 50 gr., 85 gr., 15 gr.; (5) 15 gr., 85 gr., 50 gr.

In going up and down the series from No. I to 13 and 13 to $I$, the order was varied, in each sitting, and from sitting to sitting. 
The following shows the form of the record kept for the judgments of each subject.

TABLE A.

\begin{tabular}{|c|c|c|c|c|c|c|c|c|c|c|c|}
\hline & $\begin{array}{l}\text { STAN } \\
\text { XIGHT } \\
\text { ENGTH }\end{array}$ & $\begin{array}{l}\text { SDARD. } \\
\text { r, } 50 \text { GR. } \\
1,4^{8} \mathrm{MM} .\end{array}$ & & & $\begin{array}{l}\text { STA } \\
\text { EIGHT } \\
\text { ENGTH }\end{array}$ & $\begin{array}{l}\text { DARD. } \\
, \quad 15 \mathrm{GR} . \\
4^{8} \mathrm{MMM} .\end{array}$ & & & $\begin{array}{r}\text { Stant } \\
\text { WEIGHT } \\
\text { LENGTH }\end{array}$ & $\begin{array}{l}\text { DARD. } \\
\text { T, } 85 \text { GR. } \\
t, 48 \mathrm{MA} .\end{array}$ & \\
\hline 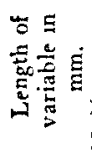 & 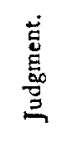 & 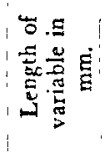 & 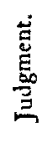 & 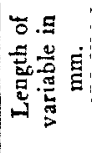 & $\begin{array}{l}\dot{\Delta} \\
\stackrel{d}{:} \\
\stackrel{\Xi}{\Xi} \\
\stackrel{\Xi}{\Xi}\end{array}$ & 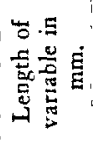 & 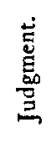 & 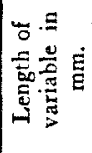 & 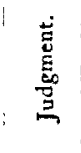 & 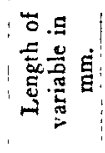 & 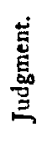 \\
\hline 54 & & 42 & & 42 & & 54 & & 54 & & 42 & \\
\hline 53 & & 43 & & 43 & & 53 & & 53 & & 43 & \\
\hline $5^{2}$ & & 44 & & 44 & & $5^{2}$ & & $5^{2}$ & & 44 & \\
\hline 51 & & 45 & & 45 & & 51 & & $5^{I}$ & & 45 & \\
\hline $5^{\circ}$ & & 46 & & 46 & & 50 & & $5^{\circ}$ & & 46 & \\
\hline 49 & & 47 & & 47 & & 49 & & 49 & & 47 & \\
\hline 48 & & 48 & & 48 & & 48 & & 48 & & 48 & \\
\hline 47 & & 49 & & 49 & & 47 & & 47 & & 49 & \\
\hline 46 & & 50 & & 50 & & 46 & & 46 & & 50 & \\
\hline 45 & & $5^{\mathrm{I}}$ & & $5^{\mathrm{I}}$ & & 45 & & 45 & & $5^{I}$ & \\
\hline 44 & & $5^{2}$ & & $5^{2}$ & & 44 & & 44 & & $5^{2}$ & \\
\hline 43 & & 53 & & 53 & & 43 & & 43 & & 53 & \\
\hline 42 & & 54 & & 54 & & 42 & & 42 & & 54 & \\
\hline
\end{tabular}

Results by the Method of Minimal Changes.

In order to estimate the results of this method the various judgments were tabulated as follows:

The 'calculated equality-point' was determined by taking the length of the block at which the judgments 'longer' stop, and also of that at which the judgments 'shorter' stop, and taking their arithmetic mean. The difference between the two values which enter into such a mean is stated, under the heading 'zone of doubt.' The results thus obtained from each series of 13 'lifts' is put in the table as a separate entry; and at the bottom the average of these and the median. Under $\mathrm{V}$ are entered the variations of the 'equality point' from the average.

The following are the tables for all the subjects: 
Table I.

Subject Ba.

\begin{tabular}{|c|c|c|c|c|c|c|c|c|}
\hline \multicolumn{3}{|c|}{ StaNDARD 50 GR. } & \multicolumn{3}{|c|}{ STANDARD I5 GR. } & \multicolumn{3}{|c|}{ Standard 85 Gr. } \\
\hline $\begin{array}{c}\text { Calculated } \\
\text { equality } \\
\text { point. }\end{array}$ & v. & $\begin{array}{c}\text { Zone } \\
\text { of } \\
\text { doubt. }\end{array}$ & $\begin{array}{c}\text { Calculated } \\
\text { equality } \\
\text { point. }\end{array}$ & v. & $\begin{array}{c}\text { Zone } \\
\text { of } \\
\text { doubt. }\end{array}$ & $\begin{array}{c}\text { Calculated } \\
\text { equality } \\
\text { point. }\end{array}$ & v. & $\begin{array}{c}\text { Zone } \\
\text { of } \\
\text { doubt. }\end{array}$ \\
\hline$m m$. & & $m m$. & $m m$. & & $m m$. & $m m$. & ! & $m m$. \\
\hline 49.5 & .4 & I & $47 \cdot 5$ & I. 3 & $I$ & 52. & 2.45 & 2 \\
\hline $49 \cdot 5$ & .4 & I & $49 \cdot 5$ & .7 & I & 50.5 & .95 & I \\
\hline $49 \cdot 5$ & .4 & I & $47 \cdot 5$ & I. 3 & I & 505 & .95 & I \\
\hline 48.5 & .6 & I & 50.5 & 1.7 & I & $49 \cdot 5$ & .05 & I \\
\hline $49 \cdot 5$ & .4 & $I$ & $47 \cdot 5$ & I. 3 & $\mathbf{I}$ & 48.5 & 1.05 & $\mathbf{I}$ \\
\hline $49 \cdot 5$ & .4 & I & 50.5 & 1.7 & $\mathbf{I}$ & $3^{1} \cdot 5$ & 1.95 & I \\
\hline 48.5 & .6 & I & 50.5 & I.7 & I & 46.5 & 3.05 & I \\
\hline 46.5 & 2.6 & $\mathbf{I}$ & 48.5 & $\cdot 3$ & 3 & $4^{8} \cdot 5$ & 1.05 & $I$ \\
\hline $5^{\mathrm{I}} \cdot 5$ & 2.4 & I & $47 \cdot 5$ & $1 \cdot 3$ & I & 50.5 & .95 & $I$ \\
\hline 48.5 & .6 & $\mathbf{I}$ & 48.5 & $\cdot 3$ & 1 & $47 \cdot 5$ & 2.05 & I \\
\hline Ave'ge 49.1 & .88 & I. & 48.8 & I. 16 & I. 2 & 49.55 & 1.35 & 1.1 \\
\hline Median 49.5 & & & 48.5 & & 1 & 50. & & \\
\hline
\end{tabular}

TABLE II.

Subject $B u$.

\begin{tabular}{|c|c|c|c|c|c|c|c|c|}
\hline \multicolumn{3}{|c|}{ Standard $50^{\circ} \mathrm{Gr}}$. & \multicolumn{3}{|c|}{ STANDARD I5 GR. } & \multicolumn{3}{|c|}{ STANDAKD $85 \mathrm{Gr}$. } \\
\hline $\begin{array}{l}\text { Calculated } \\
\text { equality } \\
\text { point. }\end{array}$ & v. & $\begin{array}{c}\text { Zone } \\
\text { of } \\
\text { doubt. }\end{array}$ & $\begin{array}{c}\text { Calculated } \\
\text { equality } \\
\text { point. }\end{array}$ & v. & $\begin{array}{c}\text { Zone } \\
\text { of } \\
\text { doubt. }\end{array}$ & $\begin{array}{c}\text { Calculated } \\
\text { equality } \\
\text { point. }\end{array}$ & v. & $\begin{array}{l}\text { Zone } \\
\text { of } \\
\text { doubt. }\end{array}$ \\
\hline $\mathrm{mm}$. & & $\mathbf{m m}$. & $\mathrm{mm}$. & & $m m$ & $m m$. & & mm. \\
\hline 50.5 & I. 45 & 3 & $49 \cdot 5$ & 2.1 & I & 49. & .35 & 2 \\
\hline 50.5 & $\mathrm{r} .45$ & 3 & 50. & 2.6 & 2 & 50. & 1.35 & 2 \\
\hline 48. & 1.05 & 2 & 49. & 1. 6 & 2 & 48.5 & .15 & 3 \\
\hline 49.5 & .45 & I & $4^{8} \cdot 5$ & I. I & 3 & 49. & .35 & 2 \\
\hline 47. & 2.05 & 2 & 47. & .4 & 2 & 49. & .35 & 2 \\
\hline 47 & 2.05 & 2 & 42. & $5 \cdot 4$ & 4 & 47.5 & 1.15 & I \\
\hline $49 \cdot 5$ & .45 & 3 & 46 & 1.4 & 2 & $4^{8} .5$ & .15 & 3 \\
\hline $47 \cdot 5$ & I. 55 & I & $47 \cdot 5$ &. $\mathrm{I}$ & I & $4^{8} .5$ & .15 & 3 \\
\hline $5 \mathrm{I}$. & 1.95 & 2 & 47. & .4 & 2 & $47 \cdot 5$ & 1.15 & 2 \\
\hline 50. & .95 & 2 & 47.5 & .1 & 2 & 49. & $\cdot 35$ & I \\
\hline Ave'ge 49.05 & I. 34 & 2.1 & 47.4 & 1.52 & 2.1 & 48.65 & .55 & 2.1 \\
\hline Median 49.5 & & & $47 \cdot 5$ & & & 48.75 & & \\
\hline
\end{tabular}


TABLE III.

Subject $C$.

\begin{tabular}{|c|c|c|c|c|c|c|c|c|}
\hline \multicolumn{3}{|c|}{ STANDARd 50 GR. } & \multicolumn{3}{|c|}{ Standard IS GR. } & \multicolumn{3}{|c|}{ STANDARD 85 Gr. } \\
\hline $\begin{array}{l}\text { Calculated } \\
\text { equality } \\
\text { point. }\end{array}$ & v. & $\begin{array}{c}\text { Zone } \\
\text { of } \\
\text { doubt. }\end{array}$ & $\begin{array}{c}\text { Calculated } \\
\text { equality } \\
\text { point. }\end{array}$ & v. & $\begin{array}{c}\text { Zone } \\
\text { of } \\
\text { doubt. }\end{array}$ & $\begin{array}{c}\text { Calculated } \\
\text { equality } \\
\text { point. }\end{array}$ & v. & $\begin{array}{l}\text { Zone } \\
\text { of } \\
\text { doubt. }\end{array}$ \\
\hline $\begin{array}{l}m m \\
48\end{array}$ &.$I$ & $\begin{array}{c}m m . \\
4\end{array}$ & $\begin{array}{c}m m \\
47\end{array}$ & .45 & $\begin{array}{c}m m . \\
2\end{array}$ & $\begin{array}{c}m m . \\
49.5\end{array}$ & .9 & $\begin{array}{c}m m \\
3\end{array}$ \\
\hline $47 \cdot 5$ & .4 & 3 & 46. & I. 45 & 2 & 48. & .6 & 2 \\
\hline 48. & . I & 2 & 49. & 1.55 & 2 & 49. & .4 & 2 \\
\hline 49 . & I.I & 4 & 495 & 2.05 & 5 & 49. & .4 & 2 \\
\hline 48. & .1 & 2 & 46 & $\mathrm{I} .45$ & 2 & 48.5 & .1 & 3 \\
\hline 48.5 & .6 & 7 & $47 \cdot 5$ & .05 & 3 & 49. & .4 & 2 \\
\hline $47 \cdot 5$ & 4 & 3 & $48 \cdot 5$ & 1.05 & 3 & $47 \cdot 5$ & 1.1 & 3 \\
\hline 48. & $I$ & 4 & $45 \cdot 5$ & I. 95 & 3 & $47 \cdot 5$ & I. I & 3 \\
\hline 47. & .9 & 4 & 47. & .45 & 4 & 49. & .4 & 2 \\
\hline $47 \cdot 5$ & .4 & I & 48.5 & 1.05 & 7 & 49. & .4 & 2 \\
\hline Ave'ge 47.9 & .42 & $3 \cdot 4$ & 47.45 & I. 15 & $3 \cdot 3$ & 48.6 & $.5^{8}$ & 2.4 \\
\hline Median 48 . & & & 47.25 & & & 49 . & & \\
\hline
\end{tabular}

TABLE IV.

Subject $D$.

\begin{tabular}{|c|c|c|c|c|c|c|c|c|}
\hline \multicolumn{3}{|c|}{ StANDARD 50 GR } & \multicolumn{3}{|c|}{ STAMDARD $15 \mathrm{GR}$. } & \multicolumn{3}{|c|}{ Strandard 85 GR. } \\
\hline $\begin{array}{l}\text { Calculated } \\
\text { equality } \\
\text { point. }\end{array}$ & v. & $\begin{array}{c}\text { Zone } \\
\text { of } \\
\text { doubt. }\end{array}$ & $\begin{array}{c}\text { Calculated } \\
\text { equality } \\
\text { point. }\end{array}$ & v. & $\begin{array}{c}\text { Zone } \\
\text { of } \\
\text { doubt. }\end{array}$ & $\begin{array}{c}\text { Calculated } \\
\text { equality } \\
\text { point. }\end{array}$ & v. & $\begin{array}{c}\text { Zone } \\
\text { of } \\
\text { doubt. }\end{array}$ \\
\hline $\begin{array}{l}m m . \\
52 .\end{array}$ & 2.6 & $\begin{array}{c}m m . \\
2\end{array}$ & $\begin{array}{c}\mathrm{mm} . \\
47.5\end{array}$ & .35 & $\begin{array}{c}m m . \\
9\end{array}$ & $\begin{array}{l}\mathrm{mm} . \\
50.5\end{array}$ & .55 & $\begin{array}{l}m m . \\
5\end{array}$ \\
\hline 49.5 &. $\mathrm{I}$ & 5 & $45 \cdot 5$ & $2 \cdot 35$ & 7 & 49 . & .95 & 4 \\
\hline 48.5 & .9 & 3 & 47 . & .85 & 8 & 50. & .05 & 4 \\
\hline 48.5 & .9 & I & 49. & I. 15 & 2 & 50. & .05 & 4 \\
\hline 49. & .4 & 8 & 47. & .85 & 8 & 49 . & .95 & 4 \\
\hline 50.5 & I. I & 3 & 48 & .15 & 6 & 50. & .05 & 6 \\
\hline $49 \cdot 5$ & 5 . & 3 & 50. & 2.15 & 4 & 50 & .05 & 2 \\
\hline 47. & 2.4 & 6 & $49 \cdot 5$ & 1.65 & 5 & 50.5 & .55 & 5 \\
\hline 49. & .4 & 2 & $47 \cdot 5$ & .35 & 5 & $5^{I} \cdot 5$ & I. 55 & I \\
\hline 50.5 & I. I & $\mathbf{I}$ & $47 \cdot 5$ & .35 & 7 & 49. & .95 & 2 \\
\hline Ave'ge 49.4 & I. & $3 \cdot 4$ & 47.85 & 1.02 & 6.1 & 49.95 & .57 & $3 \cdot 7$ \\
\hline Median 49 & & & $47 \cdot 5$ & & & 50. & & \\
\hline
\end{tabular}


TABLE V.

Subject $F$.

\begin{tabular}{|c|c|c|c|c|c|c|c|c|}
\hline \multicolumn{3}{|c|}{ Standard 50 Gr. } & \multicolumn{3}{|c|}{ StaNdaRd 15 Gr. } & \multicolumn{3}{|c|}{ STANDARD 85 GR. } \\
\hline $\begin{array}{l}\text { Calculated } \\
\text { equality } \\
\text { point. }\end{array}$ & v. & $\begin{array}{c}\text { Zone } \\
\text { of } \\
\text { doubt. }\end{array}$ & $\begin{array}{l}\text { Calculated } \\
\text { equality } \\
\text { point. }\end{array}$ & v. & $\begin{array}{c}\text { Zone } \\
\text { of } \\
\text { doubt. }\end{array}$ & $\begin{array}{l}\text { Calculated } \\
\text { equality } \\
\text { point. }\end{array}$ & v. & $\begin{array}{c}\text { Zone } \\
\text { of } \\
\text { doubt. }\end{array}$ \\
\hline$m m$. & & $m m$. & $m m$. & & $m m$ & $m m$. & & $m m$ \\
\hline $5^{2}$. & $3.85:$ & 6 & 46.5 & .6 & 3 & $5^{0.5}$ & 1.8 & 9 \\
\hline 48. & .15 & 4 & 47 . & .1 & 2 & $47 \cdot 5$ & 1.2 & 5 \\
\hline 49. & .85 & 6 & 45 . & 2.1 & 2 & 50 & $1 \cdot 3$ & 6 \\
\hline $4^{6} .5$ & I. 65 & 3 & 46 & I. I & 4 & 47. & 1.7 & 6 \\
\hline $5^{\circ}$. & 1.85 & 6 & 46 & I. I & 2 & 48.5 & .2 & I \\
\hline 46. & 2.15 & 2 & $49 \cdot 5$ & 2.4 & I & $45 \cdot 5$ & 3.2 & 3 \\
\hline 48.5 & .35 & I & 46.5 & .6 & I & 46.5 & 2.2 & I \\
\hline $47 \cdot 5$ & .65 & I & $49 \cdot 5$ & 2.4 & I & 50.5 & 1.8 & I \\
\hline 46.5 & 1.65 & I & 46.5 & .6 & I & $5^{I} \cdot 5$ & 2.8 & I \\
\hline $47 \cdot 5$ & 65 & $I$ & $4^{8} \cdot 5$ & 1.4 & I & $49 \cdot 5$ & .8 & I \\
\hline Av'age 48.15 & $1.3^{8}$ & 3.1 & $47 \cdot 1$ & I. 24 & I. 8 & 48.7 & I. 7 & $3 \cdot 4$ \\
\hline Median 47.75 & & & 46.5 & & & 49 . & & \\
\hline
\end{tabular}

TABLE VI.

Subject $S$.

\begin{tabular}{|c|c|c|c|c|c|c|c|c|}
\hline \multicolumn{3}{|c|}{ Standard $50 \mathrm{Gr}$. } & \multicolumn{3}{|c|}{ StANDARD 15 GR. } & \multicolumn{3}{|c|}{ Standard 85 GR. } \\
\hline $\begin{array}{l}\text { Calculated } \\
\text { equality } \\
\text { point. }\end{array}$ & v. & $\begin{array}{c}\text { Zone } \\
\text { of } \\
\text { doubt. }\end{array}$ & $\begin{array}{c}\text { Calculated } \\
\text { equality } \\
\text { point. }\end{array}$ & v. & $\begin{array}{c}\text { Zone } \\
\text { of } \\
\text { doubt. }\end{array}$ & $\begin{array}{c}\text { Calculated } \\
\text { equality } \\
\text { point. }\end{array}$ & v. & $\begin{array}{c}\text { Zone } \\
\text { of } \\
\text { doubt. }\end{array}$ \\
\hline$m m$ & & $m m$. & $m m$. & & $m m$ & $m m$. & & $m m$. \\
\hline 50. & .0 & 2 & $54+$ & 2.85 & I & $54+$ & 3.05 & I \\
\hline 50.5 & .5 & I & $53+$ & 1.85 & $2+$ & 47.5 & 1.95 & 8 \\
\hline $5^{0} \cdot 5$ & .5 & 3 & $5^{\circ}$ & 1.15 & 2 & $5^{1} \cdot 5$ & .55 & 5 \\
\hline $5^{1}$. & I. & 4 & 50 & I. 15 & 2 & 49.5 & I. 45 & I \\
\hline $5^{\mathrm{I}} \cdot 5$ & 1.5 & 3 & 53 & I. 85 & 2 & $5 \mathrm{I}$ & .05 & 2 \\
\hline 47. & 3. & 4 & $49 \cdot 5$ & I. 65 & 7 & 50.5 & .45 & I \\
\hline 50. & .0 & 2 & 53 & I. 85 & 2 & $5^{2} \cdot 5$ & 1. 55 & I \\
\hline $47 \cdot 5$ & 2.5 & 3 & $5^{1} \cdot 5$ & .35 & I & 50 & .95 & 4 \\
\hline 51. & I. & 2 & 48.5 & 2.65 & I & $5^{0.5}$ & .45 & I \\
\hline $5^{1}$ & I. & 4 & 49. & 2.15 & 2 & $5^{1}$. & .05 & 2 \\
\hline Av'age $5^{\circ}$. & I. I & 2.8 & $5^{1.15}$ & I. 75 & 2.2 & 50.95 & 1.05 & 2.6 \\
\hline Median 50.5 & & & 50.75 & & & 50.75 & & \\
\hline
\end{tabular}


TABLE VII.

Subject $W$.

\begin{tabular}{|c|c|c|c|c|c|c|c|c|}
\hline \multicolumn{3}{|c|}{ Standard $5^{\circ} \mathrm{Gr}}$. & \multicolumn{3}{|c|}{ Standard I $5 \mathrm{Gr}$. } & \multicolumn{3}{|c|}{ Standard $85^{\circ} \mathrm{Gr}}$. \\
\hline $\begin{array}{c}\text { Calculated } \\
\text { equality } \\
\text { point. }\end{array}$ & $\mathrm{v}$. & $\begin{array}{c}\text { Zone } \\
\text { of } \\
\text { doubt. }\end{array}$ & $\begin{array}{c}\text { Calculated } \\
\text { equality } \\
\text { point. }\end{array}$ & v. & $\begin{array}{c}\text { Zone } \\
\text { of } \\
\text { doubt. }\end{array}$ & $\begin{array}{c}\text { Calculated } \\
\text { equality } \\
\text { point. }\end{array}$ & v. & $\begin{array}{c}\text { Zone } \\
\text { of } \\
\text { doubt. }\end{array}$ \\
\hline $\begin{array}{l}m m . \\
51.5\end{array}$ & $3 \cdot 1$ & $\underset{I}{m m .}$ & $\begin{array}{l}m m . \\
48 .\end{array}$ & .5 & $\begin{array}{c}m m . \\
2\end{array}$ & $\begin{array}{l}m m . \\
46.5\end{array}$ & 1.9 & $\underset{I}{m m .}$ \\
\hline 47.5 & .9 & 3 & 48.5 & .0 & 3 & 47.5 & .9 & I \\
\hline 47.5 & .9 & I & 48.5 & .0 & 1 & 48.5 & I I & I \\
\hline 46.5 & 1.9 & I & 49.5 & 1.0 & 3 & 49.5 & I.I & I \\
\hline 48 & .4 & 2 & $4^{8}$ & .5 & 2 & 48. & .4 & 2 \\
\hline 48. & .4 & 2 & 48. & .5 & 2 & $4^{8} \cdot 5$ &.$I$ & I \\
\hline 46.5 & 1.9 & I & 48. & .5 & 2 & 49.5 & I. I & 3 \\
\hline 48.5 &. $\mathrm{I}$ & 2 & 48. & .5 & 2 & 48. & .4 & 2 \\
\hline 48.5 &. $\mathrm{I}$ & I & 49. & .5 & 4 & $5^{\circ}$. & I. 6 & 2 \\
\hline $5^{I} \cdot 5$ & 3.1 & 3 & $49 \cdot 5$ & 1.0 & $I$ & 48. & .4 & 2 \\
\hline Av'age 48.4 & 1.28 & I. 7 & $4^{8} \cdot 5$ & .5 & 2.2 & 48.4 & .8 & 1.6 \\
\hline Median 48 & & & 48.25 & & & $4^{8.25}$ & & \\
\hline
\end{tabular}

Tables Explained.

Subject Ba, Table I.

Taking the averages under 'calculated equality point,' the judgments of subject $\mathrm{Ba}$ were such that the block weighing $5^{\circ} \mathrm{gr}$. (the weight of all in the series) appeared (as we may estimate) to be $49.1 \mathrm{~mm}$. long, whereas in fact it was only $48 \mathrm{~mm}$. long. That is, the estimated length made it $1.5 \mathrm{~mm}$. longer than the block really was. This difference was not the effect of weight, for the standard and the other blocks were all of the same weight. It was rather the effect of the 'constant-error,' due to the make-up of the subject plus the influence of the order of the series, etc. Now take the effect of using standard I 5 gr., $48 \mathrm{~mm}$. long. The same subject estimated on the average that the standard was $.8 \mathrm{~mm}$. longer than it really was. The question is: Did the lightening up of the standard affect the estimate 
of the length? If we suppose the 'constant-error' the same as before, namely, the tendency to make $49.1 \mathrm{~mm}$. seem equal to $48 \mathrm{~mm}$. when both weigh $50 \mathrm{gr}$., then the lightening of the standard to $15 \mathrm{gr}$. had the effect of making it seem $48.8 \mathrm{~mm}$. long, whereas the $50 \mathrm{gr}$. standard made it seem $49.1 \mathrm{~mm}$. longa difference of $.3 \mathrm{~mm}$. That is, the lightening of the standard made this standard seem $.3 \mathrm{~mm}$. shorter than the length at which the 'constant-error' placed it.

When the 85 gr. block was used as the standard the average was $49.55 \mathrm{~mm}$. That is, the standard seemed $.45 \mathrm{~mm}$. longer than the length at which the 'constant-error' placed it. By taking the median lengths instead of the average the differences of judgments became slightly more pronounced. For instance the median with the $50 \mathrm{gr}$. block as standard was $49.5 \mathrm{~mm}$. That of the $15 \mathrm{gr}$. standard was $48.5 \mathrm{~mm}$., a lengthening of $.5 \mathrm{~mm}$. The outcome is to the effect that to lighten an object seems to reduce its length, and to weight down an object seems to increase its length.

The results with subject $\mathrm{Bu}$ indicate that to lighten an object decreases its length and to weight down an object does the same thing. In the case of subject $\mathrm{C}$, to lighten an object decreases the length and to weight down an object increases the length. Subject D's results show that to lighten an object seems to reduce its length and to weight down an object increases its length. The results of subject $F$ indicate that to lighten an object decreases its length and to weight down an object increases its length. In the case of subject $S$, to lighten an object increases its length and to weight down an object does the same thing. Subject W's results show that to lighten an object perhaps slightly increases its length and to weight down an object has little or no effect upon the estimate of its length.

From this method-that of minimal changes - the following summary statement may be made, namely, that while the results of subjects $S$ and $W$ indicate that to lighten up an object seems to increase its length, and subject $\mathrm{Ba}$ 's results show that to weight down an object seems to decrease its length, and the results of subject $W$ indicate no effect at all from weighting, yet by taking all seven subjects together the aggregated aver- 
ages show that to lighten up an object tends somewhat to decrease its length and to weight down an object slightly increases its length.

The following is the table of aggregated averages and medians:

Aggregated Averages and Medians.

\begin{tabular}{|c|c|c|c|c|c|c|c|c|c|c|c|c|}
\hline \multirow[b]{2}{*}{ 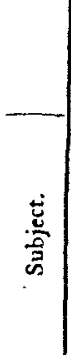 } & \multicolumn{4}{|c|}{$\begin{array}{c}\text { STANDARD. } \\
\text { WEIGHT, 5O GR. } \\
\text { LENGTH, } 48 \text { MA. }\end{array}$} & \multicolumn{4}{|c|}{$\begin{array}{c}\text { STANDARD, } \\
\text { WEIGHT, } 15 \text { GR. } \\
\text { LENGTH, } 48 \text { MN. }\end{array}$} & \multicolumn{4}{|c|}{$\begin{array}{l}\text { STANDARD. } \\
\text { WEIGTT, } 85 \text { GR. } \\
\text { LENGTH, } 4^{8} \text { MM. }\end{array}$} \\
\hline & 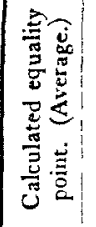 & $\vec{i}$ & 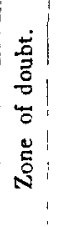 & 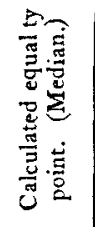 & 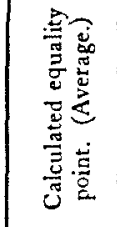 & $\begin{array}{l}\dot{2} \\
1 \\
1\end{array}$ & 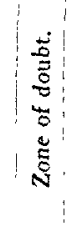 & 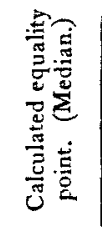 & 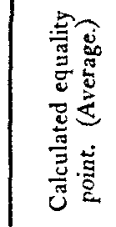 & $\dot{\Sigma}$ & 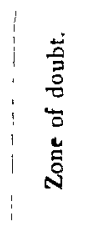 & 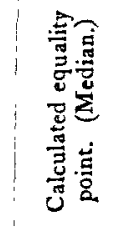 \\
\hline $\mathrm{Ba}$ & $49 \cdot I$ & $.88 \mathrm{r}$ & 1. 4 & -9.5 & 48.8 & 1. 16 & \multicolumn{2}{|c|}{ I. 248.5} & 49.55 & 1.35 & I. I & $5^{\circ}$ \\
\hline $\mathrm{Bu}$ & \multicolumn{4}{|c|}{$49.051 \cdot 342.149 .5$} & $47 \cdot 4$ & I. 52 & \multicolumn{2}{|c|}{$2.1^{\prime} 47 \cdot 5$} & 48.65 & .55 & 2.1 & .48 .75 \\
\hline $\mathrm{C}$ & \multicolumn{4}{|c|}{$47.9 \quad .423448$} & 47.45 & 1.15 & \multicolumn{2}{|c|}{$3 \cdot 347.25$} & 48.6 & $\cdot 5^{8}$ & 2.4 & 49 \\
\hline $\mathrm{D}$ & \multicolumn{4}{|c|}{$49.4:$ I. 3.449 .25} & 47.85 & 1.02 & \multicolumn{2}{|c|}{6.147 .5} & 49.95 & .57 & $3 \cdot 7$ & 50. \\
\hline $\mathrm{F}$ & \multirow{2}{*}{\multicolumn{4}{|c|}{$\begin{array}{ll:l}4^{8} .1 & \text { I. } 3^{8} 3.147 .75 \\
5^{\circ} & \text { I. I } & 2.850 .5\end{array}$}} & $47 \cdot 1$ & 1.24 & \multicolumn{2}{|c|}{1.846 .5} & 48.7 & 1.7 & 3.4 & 49 \\
\hline$S$ & & & & & 51.15 & I. 75 & \multicolumn{2}{|c|}{2.250 .75} & 50.95 & I.05 & 2.6 & $5^{\circ} .75$ \\
\hline$W$ & \multicolumn{4}{|c|}{$48.4,28 \mathrm{I} .748$} & 48.5 & $\cdot 5$ & \multicolumn{2}{|c|}{2.248 .25} & 48.4 & .8 & 1.6 & 48.25 \\
\hline & \multicolumn{4}{|c|}{$48.851 .052 .548 .92+$} & \multicolumn{4}{|c|}{$48.32+.1 .19+2.748 .03+$} & $49.25+$ & \multicolumn{3}{|c|}{$.94+2.4+49.39+$} \\
\hline
\end{tabular}

Results by the Method of Right and Wrong Cases.

In order to check the results obtained by the method of minimal changes the method of right and wrong cases with some modification was used and the following four of the same group of subjects were chosen, namely, $\mathrm{Bu}, \mathrm{C}, \mathrm{D}$ and $\mathrm{S}$. The same standards were employed and three blocks from the series were selected being respectively $50 \mathrm{~mm} .,{ }_{4} 8 \mathrm{~mm}$., and $46 \mathrm{~mm}$. in length. Nine cards were prepared with the following combinations written upon them; it being understood, of course, that the weight given is that of a block $48 \mathrm{~mm}$. long: 
$50 \mathrm{gr} .46 \mathrm{~mm}$.

$50 \mathrm{gr} .48 \mathrm{~mm}$.

$5 \circ \mathrm{gr} .50 \mathrm{~mm}$.
$15 \mathrm{gr} .46 \mathrm{~mm}$.

$15 \mathrm{gr} .48 \mathrm{~mm}$.

$15 \mathrm{gr} .50 \mathrm{~mm}$.
$85 \mathrm{gr} .46 \mathrm{~mm}$.

$85 \mathrm{gr} .48 \mathrm{~mm}$.

$85 \mathrm{gr} .50 \mathrm{~mm}$.

These cards were shuffled; then the combinations were placed permanently in the record in the order in which they happened to come up. For instance in the case of $\mathrm{C}$ the following is an illustration of the order in one shuffing:

\begin{tabular}{c:c}
$\begin{array}{c}\text { Gram. Wt. } \\
\text { of standard } \\
48 \mathrm{~mm} .\end{array}$ & $\begin{array}{c}\text { Mm. length } \\
\text { of varable } \\
\text { wt. } 50 \text { gr. }\end{array}$ \\
\hline 85 & 50 \\
15 & 46 \\
I5 & 50 \\
50 & 50 \\
50 & 48 \\
15 & 48 \\
85 & 48 \\
50 & 46 \\
85 & 46 \\
\hline
\end{tabular}

There were ten sets of these group combinations of nine, each set being arranged by an entirely independent shuffle, making in all ninety judgments which constituted one 'sitting' -all that was required in one day.

There were five 'sittings' for each subject, that is, four hundred and fifty judgments for each, or one thousand eight hundred judgments in all.

The blocks were offered to the subject as the shuffling of the cards called for. As before, the judgments of longer, shorter, equal, etc. - a judgment describing the second block in comparison with the first block as standard-were made after lifting in succession the two blocks.

For any one 'sitting' the following table will illustrate the distribution of judgments for the different combinations of blocks: 


\begin{tabular}{|c|c|c|c|}
\hline Pair Compared & $\begin{array}{l}\text { Judgments } \\
\text { 'Shorter' }\end{array}$ & $\begin{array}{l}\text { Judgments } \\
\text { 'Equal' }\end{array}$ & $\begin{array}{l}\text { Judgments } \\
\text { 'Longer' }\end{array}$ \\
\hline $50-46$ & 8 & 1 & $\mathbf{I}$ \\
\hline $50-48$ & I & 7 & 2 \\
\hline $50-50 \ldots \ldots \ldots$ & & $\mathrm{I}$ & 9 \\
\hline
\end{tabular}

\begin{tabular}{|c|c|c|c|}
\hline $15-46 \ldots \ldots \ldots \ldots \ldots \ldots \ldots \ldots \ldots \ldots \ldots$ & 6 & 4 & \\
\hline $\begin{array}{r}15-48 \ldots \ldots \ldots \ldots \ldots \ldots \ldots \ldots \ldots \\
15-50 \ldots \ldots \ldots \ldots \ldots \ldots\end{array}$ & 2 & 6 & 2 \\
\hline
\end{tabular}

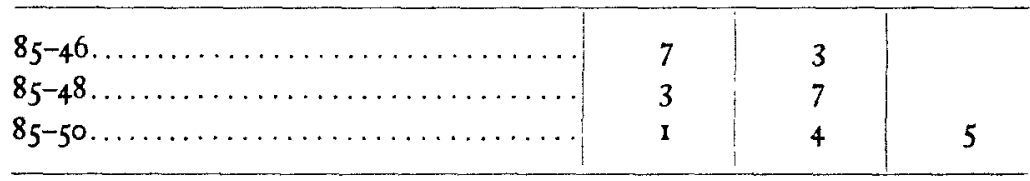

The following tables give the distribution of judgments for each subject for the five sittings:

Subject $B u$.

\begin{tabular}{|c|c|c|c|c|c|c|c|c|c|c|c|c|c|c|c|c|c|}
\hline \multirow[b]{2}{*}{$5^{0}-4^{6}}$. & \multicolumn{5}{|c|}{ 'Shorter' } & \multicolumn{5}{|c|}{ 'Equal' } & \multicolumn{5}{|c|}{ 'Longer' } & \multirow{2}{*}{$\begin{array}{c}\text { 'Equal } \\
\text { or } \\
\text { Longer' }\end{array}$} & \multirow{2}{*}{$\begin{array}{c}\text { 'Equal } \\
\text { or } \\
\text { Shorter }\end{array}$} \\
\hline & 8 & 9 & 7 & 8 & 9 & I & I & 3 & 2 & I & I & & & & & & \\
\hline $50-48 \ldots$ & I & $\mathbf{I}$ & 2 & $\mathbf{I}$ & 4 & 7 & 8 & 6 & 7 & 6 & 2 & I & 2 & 2 & & & \\
\hline $50-50 \ldots$ & & & & & & I & $\mathbf{I}$ & 4 & 2 & 6 & 9 & 9 & 6 & 8 & 4 & & \\
\hline
\end{tabular}

\begin{tabular}{r|r|r|r|l|l|l|l|l|l|l|l|l|l|l|l|l|}
\hline $15-46 \ldots$ & 6 & 9 & 7 & 4 & 7 & 4 & 1 & 2 & 4 & 2 & & & 1 & 2 & 1 \\
$15-48 \ldots$ & 2 & 2 & & 1 & & 6 & 8 & 8 & 4 & 8 & 2 & & 2 & 5 & 2 & \\
$15-50 \ldots$ & & & & & & & 2 & & 3 & 1 & 10 & 8 & 10 & 7 & 9 & \\
\hline
\end{tabular}

\begin{tabular}{l|l|l|l|l|l|l|l|l|l|l|l|l|l|l|l|l|l}
\hline $85-46 \ldots$ & 7 & 10 & 8 & 9 & 8 & 3 & & 2 & 1 & 2 & & & & & & \\
$85-48 \ldots$ & 3 & 3 & 3 & 6 & 3 & 7 & 6 & 7 & 4 & 7 & & 1 & & & & \\
$85-50 \ldots$ & 1 & & & 1 & & 4 & 5 & 6 & 5 & 9 & 5 & 5 & 4 & 4 & 1 & & \\
\hline
\end{tabular}


Subject $C$.

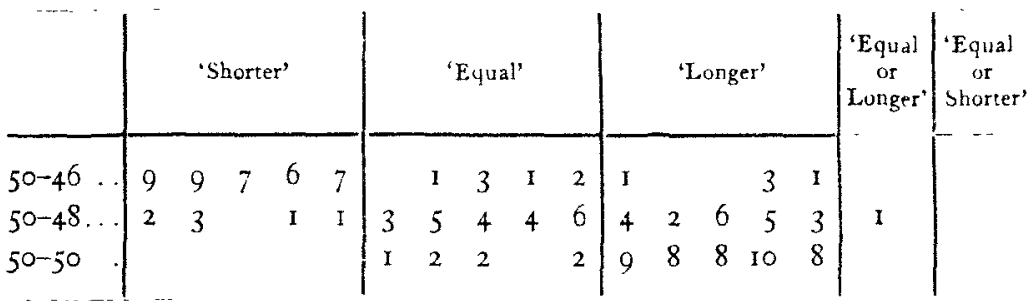

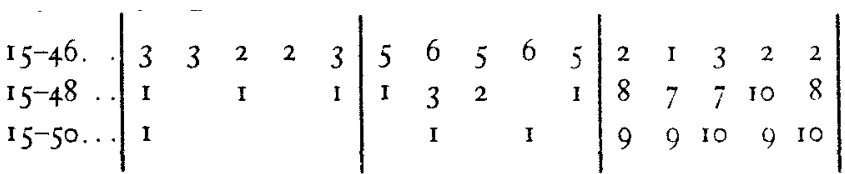

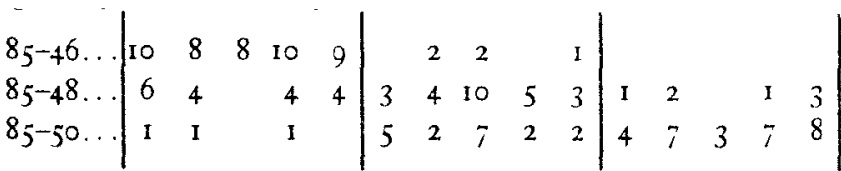

Suhject $D$

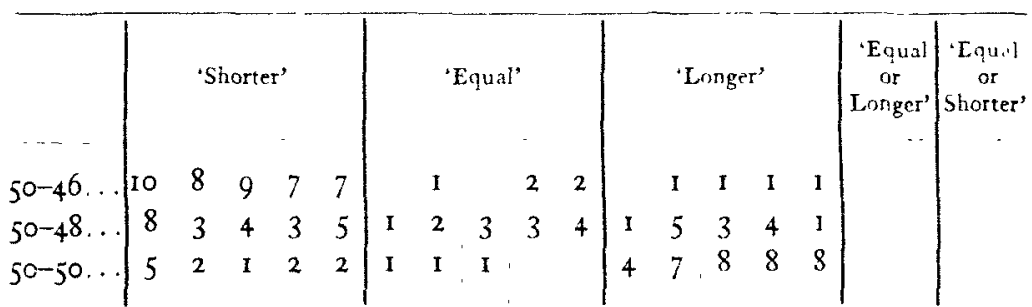

\begin{tabular}{l|lllll|lllll|lllll|}
$15-46 \ldots$ & 5 & 2 & 7 & 4 & 5 & 2 & 2 & 3 & 2 & 1 & 3 & 6 & & 4 & 4 \\
$15-48 \ldots$ & 3 & 1 & 4 & 2 & 4 & 1 & & 1 & 3 & 3 & 6 & 9 & 5 & 5 & 3 \\
$15-50 \ldots$ & 2 & & 2 & 2 & & & & 1 & 1 & 8 & 10 & 8 & 7 & 9
\end{tabular} \mid

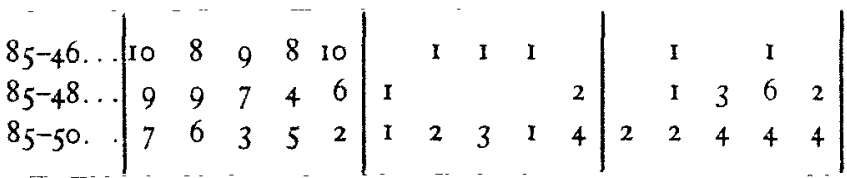


Subject $S$.

\begin{tabular}{|c|c|c|c|c|c|c|c|c|c|c|c|c|c|c|c|c|c|}
\hline & \multicolumn{5}{|c|}{ 'Shorter' } & \multicolumn{5}{|c|}{ 'Equal' } & \multicolumn{5}{|c|}{ 'Longer' } & \multirow{2}{*}{$\begin{array}{c}\text { Equal } \\
\text { or } \\
\text { Longer }\end{array}$} & $\begin{array}{c}\text { Equal } \\
\text { or }\end{array}$ \\
\hline $50-46$ & 7 & 7 & 7 & 7 & 8 & 3 & 3 & 2 & 2 & I & & & & & I & & I \\
\hline $5048 \ldots$ & 5 & 8 & 5 & 4 & 4 & 4 & I & 3 & 5 & 3 & & I & 2 & I & 3 & 1 & \\
\hline $5^{\circ}-5^{\circ} \ldots$ & 3 & 2 & & $I$ & I & & 4 & 3 & 4 & 2 & 6 & 4 & 7 & 5 & 6 & 2 & \\
\hline
\end{tabular}

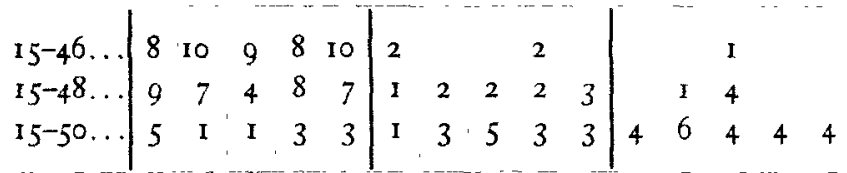

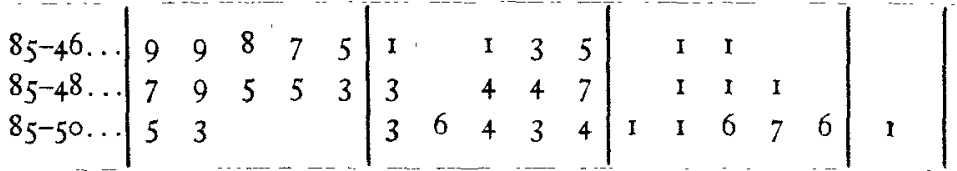

Combining them in summary the results are as follows:

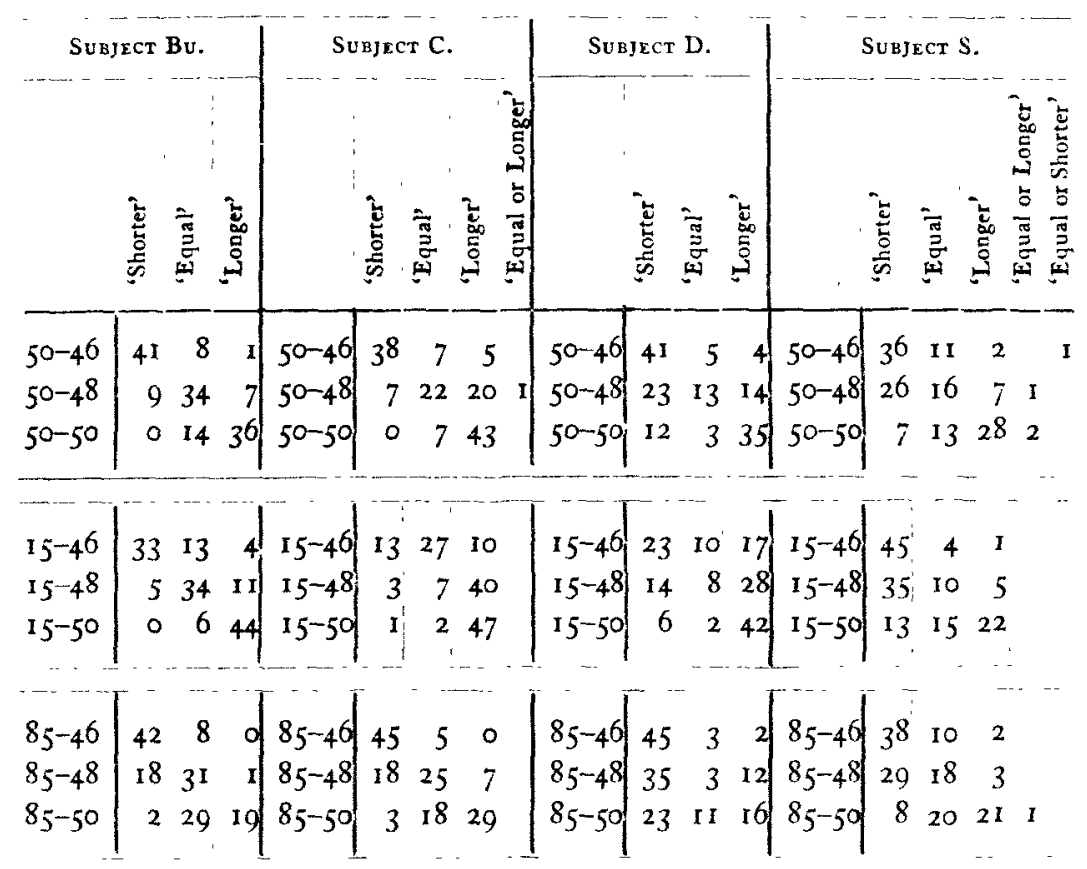


In order to estimate the results of this method let us examine the judgments of any subject from the above table, say subject S. Sixteen times he estimated block $48 \mathrm{~mm}$. 'equal' in length to standard $5^{\circ} \mathrm{gr} .\left(4^{8} \mathrm{~mm}\right.$.); twenty-six times he said it was 'shorter' than the standard, and seven times that it was 'longer,' and once he judged it either 'equal or longer'. It is evident that the 'constant-error' so influenced the estimate as to cause the subject to say twenty-six times that block $48 \mathrm{~mm}$. was 'shorter' than the $5^{\circ} \mathrm{gr}$. standard when they were actually 'equal' in length. Now take the effect of lightening the standard to $15 \mathrm{gr}$. If the lightening has no effect the result should approximate 26 'shorter,' I6 'equal,' 7 'longer' and I 'equal or longer,' but as a matter of fact it stands 35 'shorter,' Io 'equal,' and" 5 'longer.' What has been the effect of lightening? Evidently this, that nine judgments have been put into the 'shorter' column, and two have been taken from the 'longer'column. The lightening of the object thus seems to have had the effect of increasing its apparent length.

Now take the case where the standard is weighted down to $85 \mathrm{gr}$. If the weighting has no effect on the length we should expect to find the result approximately 26 'shorter,' I6 'equal,' 7 'longer' and I 'equal or longer.' But in fact we find it 29 'shorter,' 18 'equal' and 3 'longer.' That is 4 'longer,' and I 'equal or longer' have been distributed into the 'equal' and 'shorter' columns increasing these to I 8 and 29 respectively. This result indicates that increasing the weight increased the apparent length.

Taking block $46 \mathrm{~mm}$. and the $50 \mathrm{gr}$. standard, the 'constanterror' distributes the judgments as follows: 36 'shorter,' I I 'equal,' 2 'longer' and I 'shorter or equal.' Comparing that with the result when the standard is lightened, the result stands 45 'shorter,' 4 'equal' and I 'longer.' Nine judgments have been put in the 'shorter' column, indicating again that to lighten the object tends to increase its length.

For the other subjects it is only necessary to give the general conclusions. Subjects $\mathrm{Bu}, \mathrm{C}$ and $\mathrm{D}$, all show the same general result, namely, that to lighten an object is to decrease its apparent length, and to weight down an object is to increase 
its apparent length. Subject $S$ reversed this conclusion so far as lightening the standard is concerned, in this and the method of minimal changes also.

Subject Bu's judgments by this method of right and wrong cases come out somewhat different from those obtained by the method of minimal changes. By the method of minimal changes his judgments show that to weight down decreases the apparent length; but by this method - right and wrong cases-his results indicate that to weight down increases the length, i. e., his judgment here accords with those of the main group of subjects.

The following is a summary of the results of all the subjects according to both methods:

Method of Minimal Changes.

\begin{tabular}{|c|c|c|c|c|c|c|}
\hline \multirow{2}{*}{$\frac{\text { Subject. }}{\mathrm{Ba}}$} & \multicolumn{3}{|c|}{ Effect of decreasing the weight. } & \multicolumn{3}{|c|}{ Effect of uncreasing the weight. } \\
\hline & \multicolumn{3}{|c|}{ decrease of apparent size } & \multicolumn{3}{|c|}{ increase of apparent size } \\
\hline $\mathrm{Bu}$ & $"$ & “ & $"$ & decrease & “ & “ \\
\hline $\mathrm{C}$ & “ & “ & “ & increase & “ & “ \\
\hline $\mathrm{D}$ & “ & “ & " & " & “ & " \\
\hline F & " & " & “ & “ & “ & “ \\
\hline$S$ & increase & " & “ & “ & “ & “ \\
\hline W & " & $"$ & “ & \multicolumn{3}{|c|}{ seems not to affect size } \\
\hline
\end{tabular}

Method of Rightand Wrong Cases.

\begin{tabular}{|c|c|c|c|c|c|c|}
\hline \multirow{2}{*}{$\frac{\text { Subject. }}{\mathrm{Bu}}$} & \multicolumn{3}{|c|}{ Effect of decreasing the weight. } & \multicolumn{3}{|c|}{ Effect of increasing the weight } \\
\hline & \multicolumn{3}{|c|}{ decrease of apparent size } & \multicolumn{3}{|c|}{ increase of apparent size } \\
\hline $\mathrm{C}$ & “ & 4 & “ & “ & “ & " \\
\hline $\mathrm{D}$ & $"$ & “ & “ & $"$ & “ & $"$ \\
\hline$S$ & increase & “ & « & “ & “ & « \\
\hline
\end{tabular}

It is evident, taking both methods together, that for most persons, and after making allowance for the constant error due to the succession in comparison, to lighten up an object seems to decrease its length and to weight down an object seems to 
increase its length. We thus have an illusion in tactual spaceperception that in some respects is, and in some respects is not, the converse of the weight-size illusion.

The exact converse of the weight-size illusion would be something as follows:

The illusion would start from the experience which the different weights arouse. Experience has taught us that in general the size of things increases with their weight. The actual size of the heavier box would be so much less than we anticipated and so much less than we had prepared the hand to grasp that by contrast it would seem smaller than it actually was. Its size would be underestimated and for like reasons the size of the lighter box would be overestimated.

We have said that the actual illusion found by these experiments in some respects is, and in some respects is not, the converse of the weight-size illusion. It is the converse of it in this, that the variation of weight has an influence upon the judgment of extent: whereas in the weight-size illusion the variation of size has an influence upon the judgment of weight. It is not the converse, however, with regard to the exact character of this influence. In the weight-size illusion it is found that to increase the size tends to the apparent decrease of weight, and that to decrease the size tends to an apparent increase of weight. The converse of this would be the apparent increase of size with the decrease of weight and the apparent decrease of size with the increase of weight. But we have found by these experiments that in most cases the decrease of weight apparently decreases the size and the increase of weight apparently increases the size. But in one case increase in weight seems to decrease the apparent size and in two other cases to decrease the weight seems to increase the apparent size; so that in three instances we have to a greater extent the converse of the weight size illusion; while in all the other cases the results are the converse only to the extent above stated.

Insofar as these results are not the exact converse of the weightsize illusion their departure is perhaps to be explained as follows: The method or way of judging here was unquestionably different from that employed normally in the weight-size illu- 
sion. In the weight-size illusion the heavier box is estimated as larger, in advance of actual touch, and the hand is prepared to clasp it as such; but, as felt -in contrast with what was estimated as its size--it feels much smaller than it otherwise would; whereas in the illusion herein described the method is different. The estimate is not made in advance of touch but as its result. The heavier block is estimated as larger than it really is because it is ingrained in us that volume increases with weight. The lighter block is estimated as smaller for like reasons.

The reason for the illusion disclosed by the present experiments is that experience or custom has taught us that in general the weights of things decrease or increase with their volume. This has become so ingrained that we are influenced when the weight is increased to say that there is also an increase in the volume, although the volume remains constant; and when the weight is decreased, to say, that the volume is decreased also, the volume remaining constant.

In the cases of subjects $S$ and $W$ where an increase of apparent size tends to decrease the weight the probable explanation may be found in a failure to find in the object the size which was anticipated because of the decrease of weight; and the result by way of contrast and by a sort of disappointment was an apparent increase of size. 